\title{
Speech Act Disagreement among Young Men in Iran
}

\author{
Afroozeh Heidari ${ }^{1, *}$, Abbas Eslami Rasekh ${ }^{2}$, Shahla Simin ${ }^{2}$ \\ ${ }^{1}$ English Department, Najafabad Branch, Islamic Azad University, Najafabad, Iran \\ ${ }^{2}$ Faculty of Foreign Languages, University of Isfahan, Isfahan, Iran \\ *E-mail address: afroozheidari@gmail.com
}

\begin{abstract}
Speech act of disagreement is one of the least attended among all the other types of speech act. The present study seeks to find out the ways in which this inherently threatening act is expressed by young male Persian speakers. To gather the needed data one hundred participants randomly selected from among a population of BA and MA students of Isfahan and Najafabad universities were asked to complete a discourse completion test (DCT) designed by the researchers. The respondents were to read six natural situations, and react to them via making disagreements. As the major focus of the study was the role that gender and power play in the application of politeness strategies, the participants were expected to disagree with two higher power interlocutors (one male and one female), two peers (one male and one female) and two addressees with lower power status (one male and one female). In order to analyze the units of disagreement, Muntigl and Turnbull's taxonomy (1995) was employed. Students' responses were further compared with Brown and Levinson's politeness strategies. The results revealed that respondents use confrontational strategies more frequently whenever expressing their oppositions to a person with the same sex which could be explained with regards to the effect of social solidarity which can potentially over rule the effect of power and gender differences.
\end{abstract}

Keywords: Speech act; Disagreement; Gender; Power; Politeness strategies

\section{INTRODUCTION}

While communicating with others we may use words to perform various actions such as making apology, giving thanks, expressing disagreement, making requests, and so on (Yule, 1996, p. 46), but the point that worth mentioning is that some of these speech acts (refusal, disagreement, etc.) may put the relationship between interlocutors in a great danger, therefore application of politeness strategies is vital for maintaining face (Locher, 2004).

Whenever using strategies of politeness to soften the threat from the inherently threatening act of disagreement, people consider different social factors such as power, solidarity, age and gender (Liu, 2004). Power, the major factor in the process of strategy selection means the unequal balance which can stern from a number of sources, including a person's ability with the language itself, his social status in relation to the other person, constraints imposed by the topic, age differences, etc. (Shuy, 1987).

Gender, as another influential factor has been a controversial issue in sociolinguistics. The current study aims to deal with the roles that both of afore mentioned factors may have in given contexts of speech. 


\section{LITERATURE REVIEW}

While considering the previous studies one can see that the politeness theory of Brown and Levinson $(1978,1987)$ and studies from Scollon and Scollon (1995) have attracted the attention of nearly all the researchers.

The gist of the Brown and Levinson theory (1978) is that some of the speech acts are intrinsically face threatening because of neglecting the face wants of interlocutors. They define the FTAs (face threatening acts) according to the person whose face is being threatened and the type of the threatened face (negative/positive face), they also mention that when one speaker does not consider the self-image of the addressee the positive face has been neglected and whenever there is a pressure on the addressee to accept or reject the future act of the speaker there has been a case of neglecting the negative face, therefore application of Brown and Levinson's (1987) theory can lead us to the conclusion that speech act disagreement is most likely to constitute a threat to the positive face of the addressee.

Whenever performing the FTA is unavoidable, people must choose between performing the act in the most direct and efficient way (i.e. on record) or trying to lessen the effect of it (FTA) on the face of the hearer (i.e. doing it off record); type of the strategy used by an individual strongly depends on the degree of the seriousness of the FTA which will be determined via consideration of the social situation (Brown \& Levinson, 1987).

The relative power of the addressee, the degree of imposition and the social distance that exists between the speaker and the addressee are the main points that an individual considers to estimate the degree of the seriousness of an FTA (Brown \&Levinson, 1987).

As Scollon and Scollon (1995) state that the communication breakdowns mainly take place as a result of violating the pragmatic rules, one can conclude that in order to produce utterances which are socially and culturally appropriate the linguistic and pragmatic knowledge must be present at the same time.

Parvaresh and Eslami rasekh (2009) in their article "Speech act Disagreement among Young Women in Iran" Investigated the ways in which the performance of young Iranian women can be affected by the level of the solidarity and deference which exists between them and their addressees. Eighty native Farsi-speaking women university students took part in the study, and two versions of a task of discourse completion (DCT) comprising of 4 tasks were developed based on a Persian short story written by Jalal Ale Ahmad, after accumulating the needed data, Geoffrey Leech's classification of illocutionary functions were used to analyze the available data the results of their study revealed that when young women want to disagree with males the considerations of deference might override those of solidarity but when their addressee is of the same sex they sometimes use the conflictives which have the most impolite intention.

Mehregan et al (2012) also studied the effects of gender in strategy selection, the results of quantitative and qualitative analysis of their data showed a positive correlation between the conservativeness of disagreement and the degree of formality of the situations. The gender effect was also observed through female speeches in the greater degree of formality of disagreements.

Behnam and Niroomand (2011) in "An Investigation of Iranian EFL learners' Use of Politeness Strategies and Power Relations in Disagreement across Different Proficiency Levels" looked at 40 Iranian EFL learners' performance on disagreement speech act; they used a proficiency test to divide the participants in to two groups (Intermediate, UpperIntermediate) and then the needed data were collected via a DCT. The results of the study suggested a mutual relation between the uses of particular kind of politeness strategies in showing disagreement to people with different power status; more importantly, as even the performance of the learners with high level of proficiency was far from that of the native 
speakers the researchers concluded that L2 learners must be aware of second language pragmatic rules and socio-cultural constraints on speech acts as well as grammatical rules in order to have a successful communication.

Thus, careful consideration of previously conducted studies in the areas of politeness and FTA reveals the need for further research on the two influential factors of power and gender. This study can be seen as an attempt of contribution to fill in this gap.

\section{METHODOLOGY OF THE STUDY}

This study seeks to answer the following research questions:

1. What is the effect of power in observing conventions of politeness?

2. What disagreement strategies do male Persian speakers mostly employ?

3. What types of politeness strategies are employed by subjects to soften the impact of this inherently face threatening act?

4. What differences in strategy use could be expected as a result of gender?

\section{1. Participants}

One hundred Persian speaking males, who have been selected randomly from the BA and MA students of Isfahan and Najafabad University took part in the study. The participants' age ranged from 18 to 26 and they were from different regions of Iran.

\section{2. Instruments}

To gather the needed data a Discourse Completion Test (DCT) (appendix) was given to the participants. The DCT consisted of six natural situations and the subjects were supposed to read the situations and disagree with two higher statuses (one male and one female), two peers (one male and one female) and two (one male and one female) with a lower status.

\section{3. Data collection}

In order to find the appropriate answer for the previously mentioned questions, after checking the main instrument of the research (i.e. DCT) in terms of its adequacy via conducting a pilot study on 10 subjects similar to the main group, all 100 participants of the original study which have been selected randomly from the BA and MA students of Isfahan and Najafabad university were asked to fill in a discourse completion test which consists of six scenarios and specifies the gender, setting, the social distance between the interlocutors and their status relative to each other.

\section{4. Data analysis}

The participants' responses were analyzed in three steps. First, the total number of the valid responses was determined via discarding the invalid ones and then Muntigl and Turnbulls' (1998) taxonomy which recognizes five types of disagreements (i.e. Irrelevancy Claims (IC), Challenges (CH), Contradictions (CT) and Counterclaims (CC), and combination of contradictions followed by counter claims) was used to identify the utterances of disagreement and the possible relationship between power and disagreement realizations was analyzed, next the Brown and levinson's taxonomy(1987) was used for counting and analyzing the politeness strategies. 


\section{RESULTS}

As the respondents were supposed to read the six natural scenarios of the DCT within which factors such as gender, setting, social distance between the interlocutors and their status relative to each other were specified; in this part the findings of the study relevant to each of these factors will be presented and discussed for each of the situations separately.

\section{Situation 1}

The Chairman of the company you work for planned a meeting to justify employees in connection with a workshop on modern methods of marketing; at the end of the meeting she emphasizes the benefits the workshop will have for the company, but because of the high costs of organizing and the economic status of the company you entirely disagree with her opinions, how will you express your opposition?

$"$

$"$

In this situation a kind of inconsistency between the powers of interlocutors exists, as the one the speaker is disagreeing with is in a higher power and position. Table 1 summarizes the frequencies of different types of disagreement utterances used by young Persian speaking males.

Table 1. Disagreement to the chairman of the company.

\section{Types of disagreement}

Frequencies

1. Irrelevancy claims
2. Challenges
e.g. ShomA vAgheæn fekr mikonin ke bærgozAri kArgAh tuye in
shærAyet kAre AghelAneiye?
(Do you really think that organizing a workshop would be a wise
thing to do in this situation?)

3. Contradictions $21 \%$

e.g. RAstesh mæn bA tævæjoh be shærAyet feli sherkæt kAmelæn bA næzære shomA mokhAlefæm.

(Honestly, I completely disagree with your opinion according to the current status of the company.)

\section{Counterclaims}

e.g. NæzærAte shomA hæmishe rAh goshA væ be sude sherkæt bude væli fekr nemikonin ke behtære rAje be in mozu bishtær fekr beshe?

(Your opinions were always helpful, but do you not think that it would be better to think more about this issue? )

5. Counterclaims followed by contradictions $36 \%$ e.g. BA tævæjoh be shærAyete sherkæt mæn bA næzære shomA movAfegh nistæm,ælbæte shAyæd hæm hægh bA shomA bAshe. (Because of the current status of the company, I do not agree with your opinion, but perhaps you are right.) 


\section{Situation 2}

You are sitting in Dr. Omid Kalani's class who is one of the most exacting masters in your college; he describes the theories that have been obsolete for several years and declares that these are completely credible and so far pundits did not raise any alternative theory, given that you have had extensive studies in this area, how do you express your opposition?

II $"$

This situation seems to be just like the previous one, as here the same inconsistency exists between the powers of interlocutors, but the major point which makes the difference is the gender of the speaker in scenarios, in the first situation participants must disagree with a female while it is exactly the opposite for the second one, Table 2 displays the types and frequencies of disagreement expressions.

Table 2. Disagreement to the professor.

\begin{tabular}{|c|c|}
\hline Types of disagreement & Frequencies \\
\hline 1. Irrelevancy claims & 0 \\
\hline $\begin{array}{l}\text { 2. Challenges } \\
\text { e.g. OstAd jesArætæn shomA motmæenid ke tuye ketAbAi ke ækhiræn } \\
\text { chAp shode hæm hæmin mætAleb zekr shode? } \\
\text { (Professor, daringly are you sure that the same points have been mentioned in the } \\
\text { recently published books?) }\end{array}$ & $13 \%$ \\
\hline $\begin{array}{l}\text { 3. Contradictions } \\
\text { e.g. OstAd mæn fekr mikonæm mætlæbi ke ælAn færmudin kAmelæn } \\
\text { eshtebAhe chon mæn tuye in zæmine motAleAte ziAdi dAræm. } \\
\text { (Professor, I think that the point you just mentioned is completely false, because } \\
\text { I've done a lot of studies in this field.) }\end{array}$ & $34 \%$ \\
\hline $\begin{array}{l}\text { 4. Counterclaims } \\
\text { e.g. OstAd shomA hæmishe mætAleb rA be dorosti mætræh mikonin, væli } \\
\text { dær in mored mæn fekr mikonæm bAyæd be mænAbe jædidtær morAjee } \\
\text { beshe. } \\
\text { (Professor, you always perfectly discuss the materials; but I think in this case it } \\
\text { should be referred to the most recent sources.) }\end{array}$ & $18 \%$ \\
\hline $\begin{array}{l}\text { 5. Counterclaims followed by contradictions } \\
\text { e.g. OstAd mæn bA tævæjoh be motAleAti ke dAshtæm bA næzære shomA } \\
\text { mokhAlefæm,ælbate bAzæm shAyæd mæn eshtebAh mikonæm. } \\
\text { (Professor, I disagree with your opinion according to my studies, but still I may be } \\
\text { wrong.) }\end{array}$ & $29 \%$ \\
\hline 6. Silence & $6 \%$ \\
\hline
\end{tabular}

In brief careful consideration of the first two tables leads us to the point that Persian speaking males tend to be indirect while expressing their opposition to a higher status, but something even more interesting is about the conservative behavior of the respondents while disagreeing with the opposite sex. 


\section{Situation 3}

You've decided to leave work for two to three hours before the end of working hours, at the same time, Mrs. Kamali one of your colleagues comes to your room and after explaining her schedule picks, starts talking about the easiness of your job and says: the recent case which was handed over to you was just a piece of cake, but because of the difficulties you had while dealing with that case, you completely disagree with her, how do you express your opposition?

$"$ .."

In this situation, the interlocutors are status equal; Table 3 summarizes the types and frequencies of the disagreement expressions.

Table 3. Disagreement to the colleague.

\begin{tabular}{|c|c|}
\hline Types of disagreement & Frequencies \\
\hline 1. Irrelevancy claims & 0 \\
\hline $\begin{array}{l}\text { 2. Challenges } \\
\text { e.g. Sohbæte shomA kheili bi ensAfiye. } \\
\text { (What you say is unfair.) }\end{array}$ & $32 \%$ \\
\hline $\begin{array}{l}\text { 3. Contradictions } \\
\text { e.g. æslæn intor nist,kAre mæn hæm sækhtihAye khodesh rA dAre. } \\
\text { (Not at all, my work has its own difficulties too.) }\end{array}$ & $26 \%$ \\
\hline $\begin{array}{l}\text { 4. Counterclaims } \\
\text { e.g. ShAyæd hæmintor bAshe ke shomA migin,shærmænde mæn ælAn } \\
\text { æjæle dAram bAyad beram. } \\
\text { (Maybe you are right, sorry; I am in a hurry to go.) }\end{array}$ & $28 \%$ \\
\hline $\begin{array}{l}\text { 5. Counterclaims followed by contradictions } \\
\text { e.g. æslæn intori ke shomA migin nist væli dælili hæm vAse bæhs } \\
\text { kærdæn vojud nædAre chon hær kæsi næzære khodesh rA dAre. } \\
\text { (It is not what you say, but there is no reason to debate as everyone has his } \\
\text { own opinion.) }\end{array}$ & $14 \%$ \\
\hline 6. Silence & - \\
\hline
\end{tabular}

In this situation the degree of solidarity between the interlocutors were more than the first two situations, and gender as a major player had its influence on the respondents.

\section{Situation 4}

You are discussing with your friends courses of the next semester during the break between two classes; suddenly, Mr. Karimi, one of your classmates, says something about the difficulty of the courses; note that a few days ago friends who are studying in the courses you are to pass next term tell you exactly the opposite of what he says, how do you express your opposition? 
$" 1$

Table 4 displays the reality about the frequency with which the disagreement expressions were employed.

Table 4. Disagreement to the classmate.

Types of disagreement

Frequencies

\begin{tabular}{lc} 
1. Irrelevancy claims & 0 \\
\hline 2. Challenges & $42 \%$
\end{tabular}

e.g. æz kojA miduni ke intoriye? æz ki shenidi?

(How do you know? From whom did you get it?)

\section{Contradictions}

$37 \%$

e.g. EshtebAh mikoni,chon mæn æz bæchehAye term bAlAi dæghighæn æks sohbæt hAye to rA shenidæm.

(You're wrong because I heard exactly the opposite of your sayings from guys of the upper terms.)

\section{Counterclaims}

$4 \%$

e.g. ShAyæd hæmintor bAshe ke to migi.

(Maybe you are right.)

5. Counterclaims followed by contradictions

$17 \%$

e.g. Fekr nemikonæm intor bAshe,ælbæte næzære AdamA bA hæm færgh mikone dige.

(I do not think so, but different people have different ideas.)

6. Silence

0

The acquired data revealed that the respondents tend to be more direct and assertive while expressing disagreement to the one with the same power status.

\section{Situation 5}

You've decided to spend some time outdoors with your family; suddenly your little sister suggests that you go to the park. But you prefer to go to the cinema and watch the recently released movie, how do you express your opposition?

$"$

Similar to the first two situations some kind of inconsistency exists here, but contrary to them, now the speaker is the one who possesses higher status and power. 
Table 5. Disagreement to the younger sister.

Types of disagreement

Frequencies

1. Irrelevancy claims
2. Challenges
e.g. CherA cinemA nærim, mæn ke migæm pArk kheili khæste konændæst.
(Why not the movies, park is very boring.)

\section{Contradictions}

e.g. Mæn ke æsæln movAfegh nistæm.

(I completely disagree.)

4. Counterclaims

e.g. BAshe mirim pArk væli emruz næ,chon mikAym be hæme khosh begzære.

(We will go to the park, but not today because happy we want everyone to be.)

\section{Counterclaims followed by contradictions \\ $17 \%$}

e.g. mæn ke mokhAlefæm,æslæn cherA ye jAi nærim ke be hæme khosh begzære?

(I disagree, why not a place which can make everyone happy?)

6. Silence

\section{Situation 6}

You are studying sensitive documents in your room; at the same time the serviceman of company enters and starts talking about the new boss, he says: the boss is a bad-tempered person with whom you cannot come to terms at all, but because of your own interactions with the boss and what you have heard from other employees you completely disagree with him, how do you express your opposition?

"1 "

In this last situation, again a kind of power inconsistency exists and gender is playing the major role. Table 6 will reveal the reality about the responses of the participants. 
Table 6. Disagreement to the serviceman.

Types of disagreement

Frequencies

\begin{tabular}{lc}
\hline 1. Irrelevancy claims & 0 \\
\hline 2. Challenges & $11 \%$
\end{tabular}

e.g. CherA hæmchin hærfi mizæni ? bærkhord khAsi æzæshun didi?

(Why do you say so? Did you see any special behavior from him?)

3. Contradictions $28 \%$

e.g. Man ke æslæn bA næzæret movAfegh nistæm,chon khodæm hæm bAhAshun bærkhord dAshtæm.

(I do not agree at all, as I myself met him before.)

4. Counterclaims $31 \%$

e.g. ShAyæd hægh bA to bAshe væli chon ishun tAze kAreshun rA shoru kærdæn bAyæd sæbr konim bebinim ke che etefAghi miofte.

(Perhaps you are right, but as he has just started the job we have to wait and see what happens.)

\section{Counterclaims followed by contradictions \\ $23 \%$}

e.g. Mæn ke fekr nemikonæm intor bAshe,ælbæte hær kæsi næzære khodesh rA dAre.

(I don't think so, but everyone has his/her own opinion.)

6. Silence $7 \%$

Although this situation and the previous one are somehow similar, the degree of solidarity was more in the previous situation, so it can be seen that in this situation respondents were more cautious while expressing their oppositions.

\section{DISCUSSION \& CONCLUSIONS}

The current study on politeness strategies was designed to explore the influences that gender and power may have on the choice of disagreement strategies in real life contexts.

The study suggested a mutual relationship between the uses of particular kind of politeness strategies in showing disagreement to people with different gender or power status, to put it another way the results of the study indicates that young Persian speaking males tend to be more direct and assertive while disagreeing with the equal status, but something even more interesting was the conservative behavior of Persian speaking males while expressing opposition to the opposite sex.

Moreover, it is important to note that the value of different social factors such as power, gender, social distance and the degree of imposition varies from context to context. So, in order to have successful communication, it' $s$ important that each community provide enough knowledge for their people about these factors and politeness strategies. 


\section{References}

[1] Behnam B., Niroomand M., English Language Teaching 4(4) (2011) 204.

[2] Brown P., Levinson S. C. (1978). Universals in language usage: Politeness phenomena In EN Goody (Ed.), Questions and politeness: Strategies in social interaction, Cambridge (pp. 56-311). New York: Cambridge University Press.

[3] Brown P., Levinson S. C. (1987). Politeness: Some universals in language usage (Vol. 4). Cambridge; New York: Cambridge University Press.

[4] Dogancay-Aktuna S., Kamisli S. (1997). Pragmatic Transfer in Interlanguage Development: A Case Study of Advanced EFL Learners.

[5] Liu S. (2004). Pragmatic strategies and power relations in disagreement: Chinese culture in higher education. New York: Universal Publishers.

[6] Locher Miriam (2004). Power and politeness in action. Disagreements in oral communication. Berlin: Mouton de Gruyter.

[7] Muntigl P., Turnbull W., Journal of Pragmatics, 29 (1998) 225-256.

[8] Parvaresh V., Eslami Rasekh A., Comparative Literature and Culture 11(4) (2009) 2-8.

[9] Rees-Miller J., Journal of Pragmatics 32(8) (2000) 1087-1111.

[10] Scollon R., Scollon S. (1995). Intercultural communication: A discourse analysis. Oxford: Blackwell.

[11] Yule G. (1996). Pragmatics. Oxford: Oxford University Press. 


\section{Appendix A}

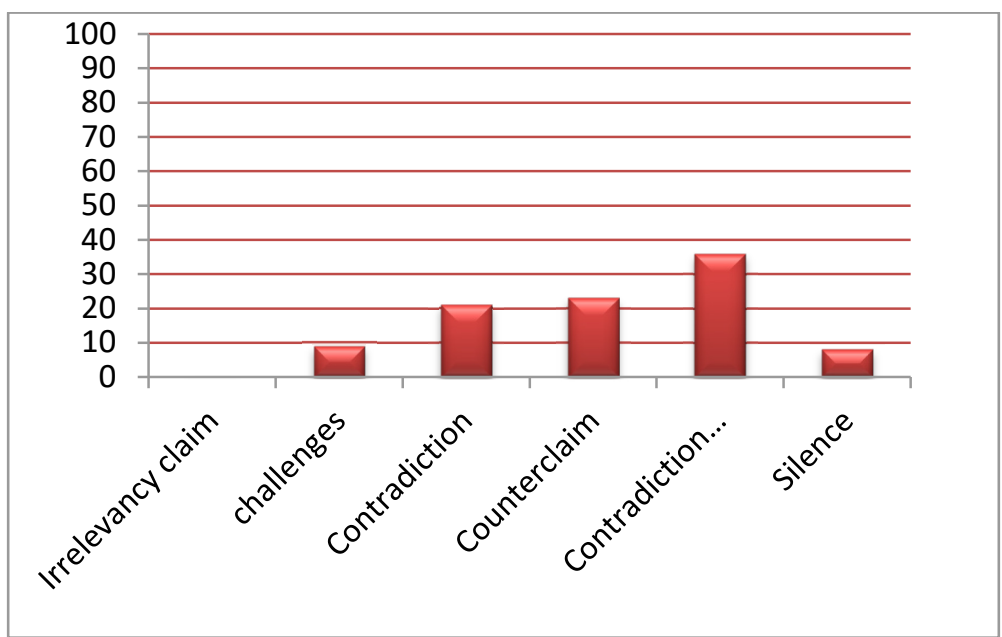

Fig. 1. Disagreement to the chairman of the company.

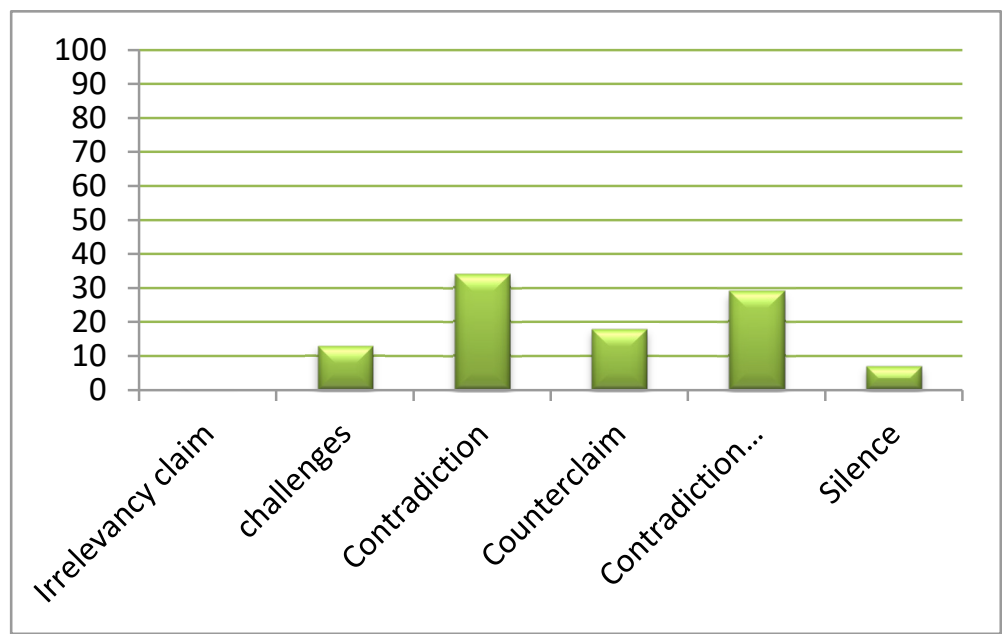

Fig. 2. Disagreement to the professor.

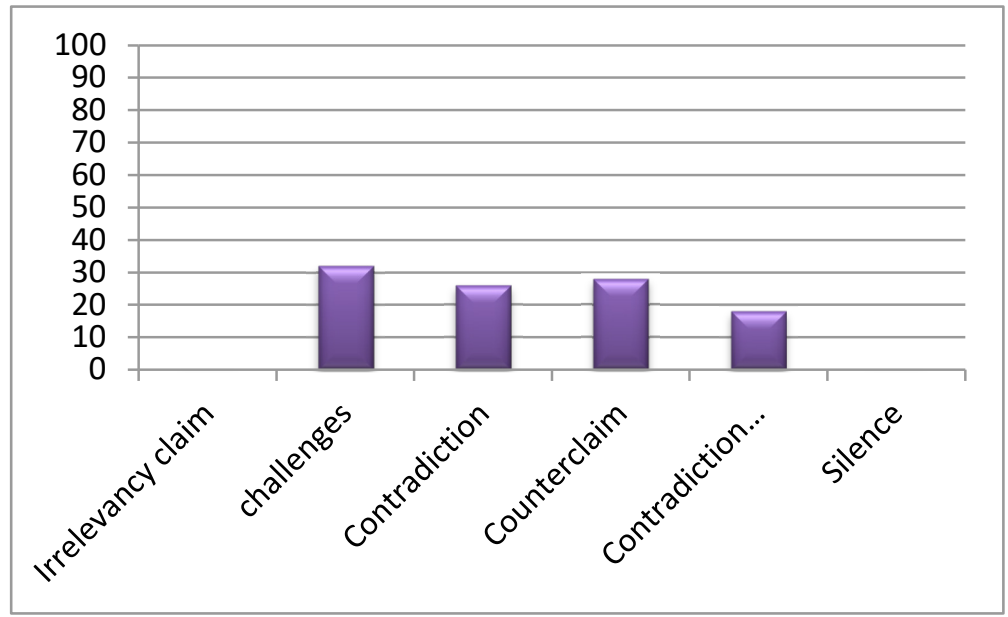


Fig. 3. Disagreement to the colleague.

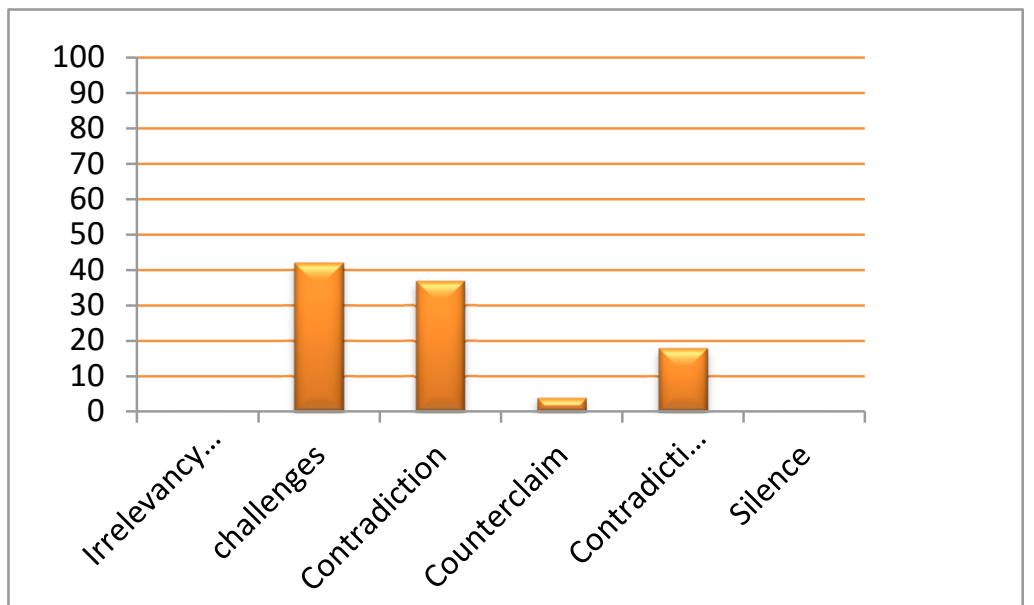

Fig. 4. Disagreement to the classmate.

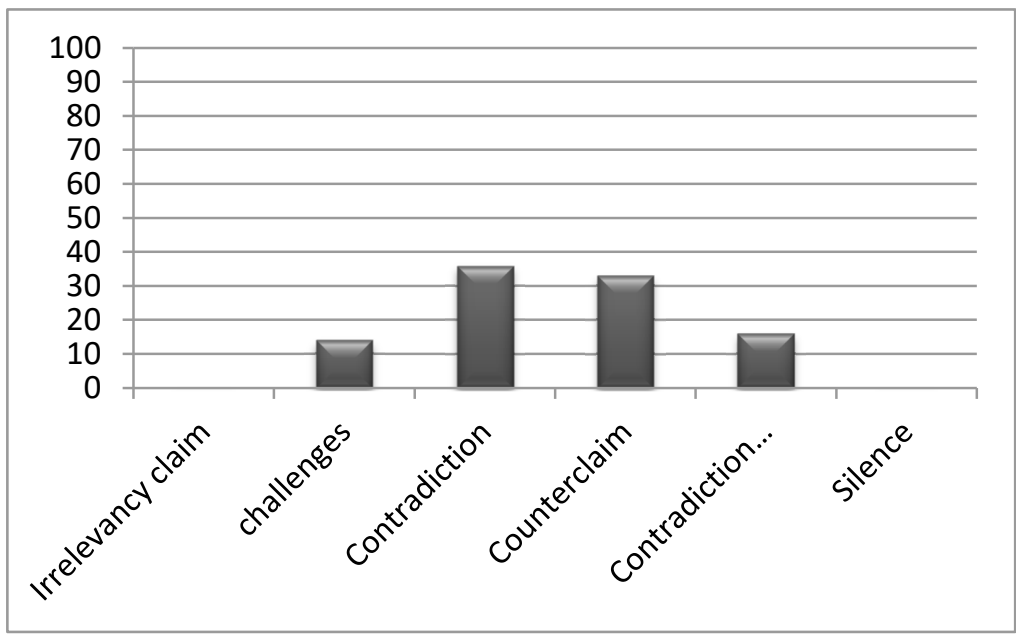

Fig. 5. Disagreement to the younger sister.

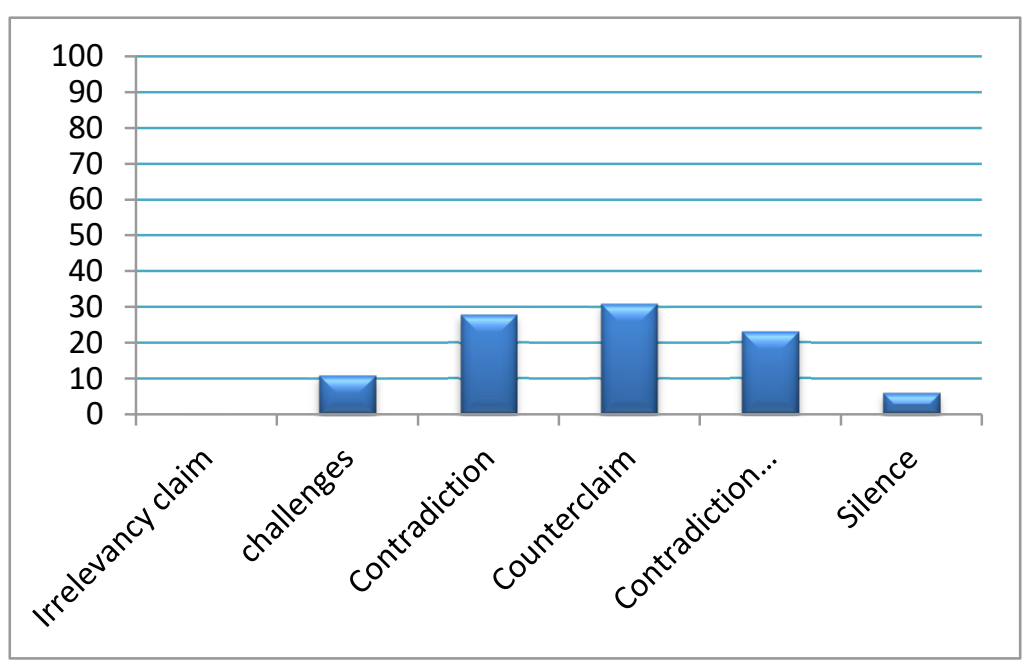

Fig. 6. Disagreement to the serviceman. 


\section{Appendix B}

\section{The English Version of the Discourse Completion Test}

Thank you very much for your time and help.

Your Age: _ Hometown:

Six scenarios are described below in which you are expected to Disagree with the speaker on different occasions.

How would you respond? Please write out what you are to SAY in real life scenarios.

1. The Chairman of the company you work for planned a meeting to justify employees in connection with a workshop on modern methods of marketing; at the end of the meeting she emphasizes the benefits the workshop will have for the company, but because of the high costs of organizing and the economic status of the company you entirely disagree with her opinions, how will you express your opposition?

2. You are sitting in Dr. Omid Kalani's class who is one of the most exacting masters in your college; he describes the theories that have been obsolete for several years and declares that these are completely credible and so far pundits did not raise any alternative theory, given that you have had extensive studies in this area, how do you express your opposition?

3. You've decided to leave work for two to three hours before the end of working hours, at the same time, Mrs. Kamali one of your colleagues comes to your room and after explaining her schedule picks, starts talking about the easiness of your job and says: the recent case which was handed over to you was just a piece of cake, but because of the difficulties you had while dealing with that case, you completely disagree with her, how do you express your opposition?

4. You are discussing with your friends courses of the next semester during the break between two classes; suddenly, Mr. Karimi, one of your classmates, says something about the difficulty of the courses; note that a few days ago friends who are studying in the courses you are to pass next term tell you exactly the opposite of what he says, how do you express your opposition?

5. You've decided to spend some time outdoors with your family; suddenly your little sister suggests that you go to the park. But you prefer to go to the cinema and watch the recently released movie, how do you express your opposition?

6. You are studying sensitive documents in your room; at the same time the serviceman of company enters and starts talking about the new boss, he says: the boss is a bad-tempered person with whom you cannot come to terms at all, but because of your own interactions with the boss and what you have heard from other employees you completely disagree with him, how do you express your opposition? 